\title{
Screening of pear germplasm against entomosporium leaf and fruit spot disease
}

\author{
S. ALTAF ${ }^{1}$, T.R. RATHER ${ }^{2 *}$, N.A. KHAN ${ }^{1}$ and Z.A. BHAT ${ }^{2}$ \\ ${ }^{1}$ Division of Plant Pathology, Sher-e-Kashmir University of Agricultural Sciences and Technology of Kashmir, Shalimar Campus, \\ Srinagar 190 025, Jammu \& Kashmir, India \\ ${ }^{2} A A R C$, Shopian, Sher-e-Kashmir University of Agricultural Sciences and Technology of Kashmir
}

Received: 28 December 2016/ Accepted: 20 February 2017/ Published online: 23 March 2017

(C) Indian Phytopathological Society 2017

\begin{abstract}
Fourteen pear varieties were screened under polyhouse conditions for their tolerance/susceptibility against entomosporium leaf and fruit spot disease. One year old healthy grafted plants of fourteen pear varieties were planted in 50 cm diameter plastic pots containing sterilized soil and were kept under polyhouse conditions equipped with sprinkler irrigation facility. The results revealed that only one cultivar i.e. Starkrimson exhibited immune reaction and six other cultivars viz., Fertility, Beurré hardy, Beurré Clairgeau, Clapp's favorite, Citron-Des-Carmes, and Max Red Bartlett were rated as moderately susceptible. The remaining cultivars viz., Chinese sandy pear, Conference, Cosia C, Cosia F, Bartlett, Red Anjou and Beurré-DeAmanalis exhibited highly susceptible reaction.
\end{abstract}

Keywords: Entomosporium, leaf and fruit spot, pear, screening

Pear (Pyrus communis L.) is one of the important pome fruits grown throughout the world. It is of great economic significance in Kashmir valley after apple, having good taste and flavour. Among various diseases, Entomosporium leaf and fruit spot, caused by the fungus Fabraea maculata (Lev.) (anamorph: Entomosporium maculatum Lev.) has assumed an alarming proportion resulting in huge economic losses through pre-mature mid-summer defoliation besides reducing the tree vigour, fruit quality and fruit yield (Goncalves et al., 2015). Infected fruits are disfigured, cracked, misshapen, and unmarketable as fresh fruit. In Kashmir valley, various chemicals are being sprayed at regular intervals to manage this important disease. However, repeated applications of fungicides increases production costs and constituted risk in terms of both environment and human health. In this study, it was aimed to determine the resistance levels of 14 available pear varieties against the Entomosporium leaf and Fruit spot disease under polyhouse conditions

Fourteen pear varieties were screened under polyhouse conditions for their tolerance/resistance against the pathogen. One year old healthy, grafted plants of fourteen pear varieties were procured from different sources and planted in $50 \mathrm{~cm}$ diameter plastic pots containing sterilized soil and were kept under polyhouse conditions equipped with sprinkler irrigation facility at Ambri Apple Research Center Shopian during 2014. High humidity inside the polyhouse was maintained by timely sprinkler irrigation. Inoculations were made by spraying

${ }^{\star}$ Corresponding author: tariq.rasool @ rediffmail.com spore suspension $1 \times 10^{4}$ spores $/ \mathrm{ml}$ of water from culture of Entomosporium maculatum on the abaxial and adaxial surface of leaves with the help of an atomizer. Prior to inoculations, the leaves were sprayed with distilled sterilized water.

The per cent disease intensity on leaves was calculated after rating the level of disease on 0-5 scale (Zarger, 1995) as described below:

\begin{tabular}{lcl}
\hline Category & $\begin{array}{c}\text { Numerical } \\
\text { value }\end{array}$ & Criterion \\
\hline I & 0 & Disease free \\
II & 1 & $1-5$ spots on leaf/fruit \\
III & 2 & $\begin{array}{l}6-10 \text { spots on leaf/fruit } \\
\text { IV }\end{array}$ \\
V & 3 & $\begin{array}{l}11-25 \text { spots on leaf/fruit } \\
\text { coalescing }\end{array}$ \\
VI & 4 & $\begin{array}{l}\text { Above } 50 \text { spots with or without } \\
\text { coalescing }\end{array}$ \\
\hline
\end{tabular}

Per cent disease intensity was calculated using the formula:

Per cent disease intensity $=\frac{\Sigma(n \times v)}{N \times G} \times 100$

Where,

$\Sigma=$ Summation

$\mathrm{n}=$ Number of diseased leaves/fruits in each category;

$v=$ Numerical value of each category; 
Table 1. Reaction of pear germplasm towards entomosporium leaf spot disease, Entomosporium maculatum Lev. under artificial inoculations

\begin{tabular}{|c|c|c|c|c|c|}
\hline Variety & $\%$ disease intensity & Disease reaction & Latent period & Lesion size $(\mathrm{mm})$ & Virulence index \\
\hline Chinese sandy pear & 65.40 & $\mathrm{HS}$ & 9 & 2.8 & 7.26 \\
\hline Fertility & 15.20 & MS & 13 & 0.90 & 1.16 \\
\hline Conference & 32.40 & $\mathrm{HS}$ & 11 & 1.21 & 2.94 \\
\hline Cosia C & 38.60 & HS & 9 & 1.38 & 4.28 \\
\hline Cosia F & 30.00 & HS & 12 & 1.03 & 2.50 \\
\hline Bartlett & 44.30 & HS & 10 & 1.15 & 4.43 \\
\hline Beurue hardy & 16.40 & MS & 14 & 0.27 & 1.17 \\
\hline Starkrimson & 0.00 & I & 0 & 0.00 & 0.00 \\
\hline Red Anjou & 36.70 & HS & 10 & 1.09 & 3.67 \\
\hline Beurre Clairgeau & 17.30 & MS & 14 & 0.18 & 1.23 \\
\hline Citron-Des-Carmes & 16.40 & MS & 13 & 0.44 & 1.26 \\
\hline Max Red Bartlett & 12.20 & MS & 14 & 0.21 & 0.87 \\
\hline Clapp's favourite & 15.20 & MS & 13 & 0.90 & 1.16 \\
\hline Beurre-De-Amanalis & 32.70 & $\mathrm{HS}$ & 10 & 1.05 & 3.27 \\
\hline
\end{tabular}

I=Immune, HR=Highly resistant, MR=Moderately resistant, MS=Moderately susceptible, HS=Highly susceptible

Table 2. Grouping of various pear varieties into different reaction categories for entomosporium leaf spot disease on per cent disease intensity

\begin{tabular}{lcl}
\hline Reaction category & $\begin{array}{c}\text { Per cent disease } \\
\text { index (PDI) }\end{array}$ & Variety \\
\hline Immune & No disease & Starkrimson \\
Highly resistant & $1-5$ & Nil \\
Moderately resistant & $5.1-10.0$ & Nil \\
Moderately susceptible & $10.1-20.0$ & $\begin{array}{l}\text { Fertility, Beurue hardy, Beurre Clairgeau, Clapp's favourite, Citron-Des-Carmes, } \\
\text { and Max Red Bartlett } \\
\text { Chinese sandy pear, Conference, Cosia C, Cosia F, Bartlett, Red Anjou, Beurrue- } \\
\text { Highly susceptible }\end{array}$ \\
& $>20$ & \begin{tabular}{l} 
De-Amanalis \\
\hline
\end{tabular}
\end{tabular}

$\mathrm{N}=$ Total number of leaves/fruits examined; and

$\mathrm{G}=$ Maximum numerical value

Disease reaction of the varieties were categorized on the basis of scale given by Hua et al. (1).

\begin{tabular}{lll}
\hline Category & $\begin{array}{l}\text { Disease } \\
\text { index }(\%)\end{array}$ & Reaction \\
\hline I & No disease & Immune (I) \\
II & $1-5$ & Resistant (R) \\
III & $5.1-10$ & Moderately resistant (MR) \\
IV & $10.1-20$ & Moderately susceptible (MS) \\
V & $>20$ & Highly susceptible (HS) \\
\hline
\end{tabular}

Latent period was taken as time in terms of number of days from inoculation to appearance of first lesion on each cultivar. The leaves were examined for the appearance of lesions everyday starting from $24 \mathrm{~h}$ after inoculation up to appearance of lesions in every variety.

The numerical values of disease reaction, disease intensity and latent period were used to calculate the virulence index with the following formula (Madhavi et al., 2015)

$$
\text { Virulence Index }(\mathrm{VI})=\mathrm{PDI} \times \mathrm{LP}^{-1}
$$

Where, $\mathrm{PDI}=$ Per cent Disease Index, $\mathrm{LP}=$ Latent period

The data as presented in table 1 revealed differential response of the cultivars to the pathogen (Table 1). All the test varieties were found susceptible to the pathogen, except Starkrimson which failed to establish its relationship with the pathogen. Maximum disease intensity of 65.40 and 44.30 per cent was recorded in variety Chinese sandy pear and Bartlett, respectively.



Fig. 1. 45 days old fungal colony with acervuli 




Fig. 2. Irregular to circular disease spots

The disease intensity was next highest in Cosia C (38.60\%), followed by variety Red Anjou exhibiting disease intensity of 36.70 per cent. Minimum disease intensities of 12.20 and 15.22 per cent were recorded in variety Max Red Bartlett; Fertility and Clapp's Favourite, respectively. Based on disease intensity the test varieties were allotted to different reaction groups. Six cultivars namely Fertility, Beurue hardy, Beurre Clairgeau, Clapp's favourite, Citron-Des-Carmes, and Max Red Bartlett with disease intensities ranging between 10.1 to 20.00 per cent were categorized as moderately susceptible. Seven cultivars namely Chinese sandy pear, Conference, Cosia C, Cosia F, Bartlett, Red Anjou and Beurrue-De-Amanalis exhibiting disease intensities of more than 20 per cent were categorized as highly susceptible. Bell and Vander (2005) also reported Bartlett and Clapp's favorite pear cultivars as highly susceptible to $E$. maculatum which supports our findings.

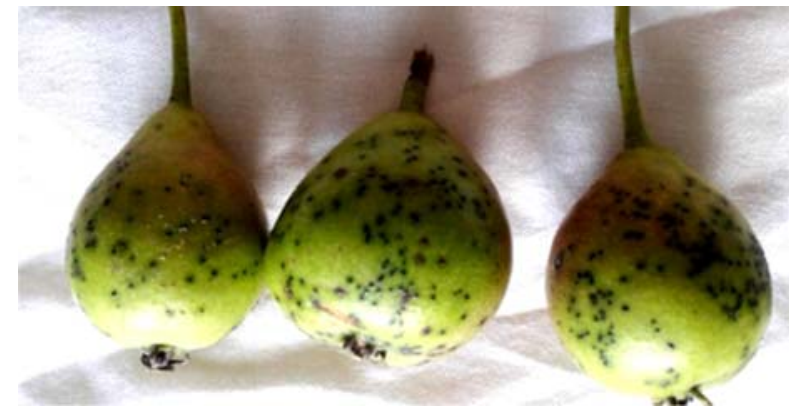

Fig. 3. Small irregular lesions on fruit

\section{REFERENCES}

Bell RL and Vander ZT (2005). Susceptibility of Pyrus germplasm to Fabraea leaf spot. Acta Hort. 224: 229-236.

Goncalves MJ, Bogo A, Rufalto L, Waldir CJ, Casa RT, Weber GC and Correa D (2013). Behaviour of European pear cultivars under different quince rootstock to Entomosporium leaf spot in southern Brazil. Crop Prot. 49: $26-30$

Hua Y, Guo H, Zhou XG, Li X, Yang S, Song Y, Chai C, Qiao X and Li L (2014). Correlation between soluble sugars and phenol contents in leaves and pear scab resistance. J. Pathol. Microbiol. 5: 1-5.

Madhavi M, Reddy PN, Reddy RR and Sudarshan MR (2015). Pathogenic variability of Rhizoctonia solani isolates causing banded leaf and sheath blight of maize in Andhra Pradesh. Indian J. Plant Prot. 43(1): 60-67.

Zargar SA (1995). Studies on biology and management of fruit spot disease of pear (Pyrus communis) caused by Entomosporium maculatum. M.Sc. Thesis submitted to Sher-e-Kashmir University of Agricultural Sciences and Technology Kashmir, pp. 41. 